How to cite this article:

Unny, A. (2020). The U.S inaction on climate change: Realism and its interpretations. Journal of International Studies, 16, 89-103. https://doi.org/10.32890/jis2020.16.6

\title{
The U.S Inaction on Climate Change: Realism and Its Interpretations
}

\author{
Anu Unny \\ Department of Political Science, \\ University of Kerala, Thiruvananthapuram, India \\ unny.anu@gmail.com
}

Received: 6/6/2020

Revised: 29/7/2020

Accepted: $11 / 8 / 2020$

Published: 30/12/2020

\begin{abstract}
President Donald Trump announced the U.S. withdrawal from the 2015 Paris Agreement, and stated that the withdrawal was mainly to protect its national interests. The U.S. economic ambitions, the China factor and the intricacies of U.S domestic politics had played a major role in deciding the U.S. position on the Paris Agreement and the Kyoto Protocol of 1997. There are some who are sceptical on whether the Paris Agreement would successfully achieve its expected outcomes in the absence of U.S. participation. The objective of this study is to examine the factors that have discouraged the U.S. to partake in the international climate change agreements. An analytical framework was employed for this study that examines the insights and conceptions from the textual data, based on realism. The study concludes that the U.S. outlook on climate change had more or less adhered to the realist stance, even though realism is considered a theoretical approach with significant drawbacks, particularly when dealing with issues of climate change. Nonetheless, this study also asserts that there is a need for deeper engagement between the U.S. and the participants of the Paris Agreement to effectively tackle the issues of climate change at this moment.
\end{abstract}

Keywords: Climate Change, Realism, Paris Agreement, U.S., China, Kyoto Protocol.

\section{Introduction}

The threat perceptions that drive the behavior of nation-states in the international system vary in different periods. In addition to the traditional security threats such as war and armed conflicts between states, new security challenges have also emerged that has demanded 
the immediate action from all countries. Climate change is such a non-traditional security threat that has been widely discussed in many international forums since the 1970s. Rapid melting of glaciers, rising sea level and changing weather patterns are the effects of global atmospheric changes that have taken place rapidly since the $20^{\text {th }}$ century. No nation-state can avoid the effects of climate change as it continues to be a trans-boundary challenge that requires immediate cooperation between nations (IPCC, 2014). The increasing global temperature levels, rampant wildfires, increasing pollution, deforestation and overall environmental degradation are posing new threats to states' security and its survival.

Climate change has become a threat that could potentially destabilize the political and economic conditions of countries by inducing domestic and interstate conflict over land, water and other natural resources (Meadowcroft, 2010). Climate-induced migration within the state and between states has already become a reality. This may have ramifications on the relationship between countries and the balance of power in global politics. The impacts of climate change varies between countries. While developing countries and small island states are viewed as being least responsible for inducing this crisis, these countries have struggled to adapt to the impacts of climate change. On the other hand, developed countries that have historically been proven to bear the responsibility for causing this problem are finding alternative approaches to mitigate the effects of climate change. This has created a political void in the international system, making it difficult for a consensus to be reached between the developed and developing states.

The establishment of the Paris Climate Agreement in 2015 was a necessary step to regulate global carbon emissions to combat climate change. However, the withdrawal of the U.S. from the Paris Agreement has made it unpredictable to evaluate the success of the accords. This study analyses the realist position on climate change in general, and the factors that have discouraged the US participation in the international climate change agreements from the perspectives of both defensive and offensive realism. The study will also attempt to address the limitations of realism in dealing with climate change.

This study employed the qualitative method to analyze the climate change problem by examining the textual data that relates to climate change and realism. This study approaches the climate change debate from a theoretical position that derives from realism. Though realism has many variants, defensive and offensive realist positions have been utilized for this study through the qualitative method to understand the U.S position on international climate agreements. Moreover, this paper is descriptive and analytical.

This study is organized into five parts. The first part of the study provides a detailed analysis of the evolution of international climate change agreements with reference to the 2015 Paris Agreement. The second part of the study is a brief account on the approaches employed by realist in the climate change debates at present. In the third part, a detailed account of the U.S position on climate change with special reference to the Kyoto Protocol and the Paris Agreement is analyzed. The fourth part of the study highlights the limitations from the realist perspective in relation to the climate change debate. The fifth part is the conclusion. 


\section{Literature Review}

The fourth and fifth assessment reports of the IPCC have concluded that human activity is the primary driver for climate change (IPCC, 2007; IPCC, 2014). The fourth Assessment Report (1PCC, 2007) warned that 'the warming of the climate system is unequivocal' and therefore, the impact of climate change would vary between countries. The fifth Assessment Report of IPCC (2014) stated that the world will face a catastrophic situation, unless and until, all countries strive to restrict global warming to 2 degrees Celsius. The report suggested that moving to a low-carbon economy that is dependent on renewable energy sources rather than conventional energy is vital for countries to combat climate change (IPCC, 2014). Energy consumption continues to be the driving force for climate change as it contributes substantially to global warming through burning of fossil fuels (Vinodan \& Kurian, 2015: 29). Since the founding of the IPCC in 1988, its scientific reports on climate change have served as a knowledge exchange platform for countries to coordinate and disseminate information on climate change. The Sixth Assessment Report of the IPCC is expected to be released in 2022 .

By retracing the history of climate change negotiations, since the 1972 UN Stockholm Conference to the 2019 Madrid Climate Conference, the climate change issue has been a subject of extensive discussion and debate in many international platforms. The United Nations Framework Convention on Climate Change (hereafter UNFCCC), an environmental treaty signed in 1992 at the Rio de Janeiro, was the first international treaty that was adopted to reduce greenhouse gases emission globally. However, this treaty had failed to cap emissions from countries, and was therefore unsuccessful in achieving its objectives. In 1997, during the Kyoto Conference, the Conference of Parties had decided to establish another climate treaty, named the Kyoto Protocol 1997. The aim of this treaty was to fix emission reduction targets for developed countries, while exempting the developing countries from adopting the requirements under the Protocol as their contribution to the problem was found to be minimal. By acknowledging the UNFCCC principle (1992, Principle 7), it was agreed that under the Common but Differentiated Responsibility principle (hereafter CBDR), all countries share the responsibility to reduce emissions, while some countries, particularly the developed countries, are required to take up more responsibility to bring down emissions as these countries have polluted the atmosphere since the industrial revolution. While all countries have the right to development, the developing countries have argued that for development to take place, the international treaty must be more conducive to the economic development of developing countries (Masum, 2013: 33). The 1997 Kyoto Protocol had failed to meet its target because countries like the United States, that have earlier signed the Protocol, neglected to ratify the Protocol domestically. The United States rejected the Protocol due to the exemption that was given to key developing countries, such as China and India, from emission reduction commitments under the Protocol. Eventually, efforts to frame an international treaty that ensures the participation from all countries in emission reduction had gained momentum and was finally concluded with the signing of the Paris Agreement in 2015. 
The non-ratification of the Kyoto Protocol by the U.S, and the withdrawal of countries such as Russia, Canada and Japan from the treaty were the two main factors that necessitated the establishment of a new agreement in Paris. The Paris Agreement (UNFCCC, 2015) framed by the Conference of Parties came into effect on $4^{\text {th }}$ November 2016. Unlike the Kyoto Protocol, the Paris Agreement (UNFCCC, 2015) dictated the voluntary emission reduction targets that are decided by the respective individual countries based on their national circumstances, while taking into account the Intended Nationally Determined Commitments (INDC). The Government of India (2015) pledged to reduce its carbon emissions from 33 percent in 2005 to 35 percent by 2030, while China promised to cut its carbon emission intensity from 60 percent in 2005 to 65 percent by 2030 (Dept. of Climate Change, National Development and Reform Commission of China, 2015). On the other hand, the United States had pledged that it would reduce its emissions from 26 percent in 2005 to 28 percent by 2025 (CRS Report, 2015).

However, one of the problems that was identified from the Paris Agreement is that the treaty is based on the voluntary emission reduction commitments that are decided by the respective countries. The treaty does not provide any provision or mechanism to punish countries that are not abiding to the Agreement, or do not meet their respective emission reduction targets. Although there are provisions under the Paris Agreement to monitor and report emission reduction by every country, it is doubtful on whether the countries are willing to cooperate in controlling their emissions. Hence, these actions will negate the effective implementation of the Agreement itself. Uncertainty and doubts on the future of the Paris Agreement were exacerbated when President Donald Trump announced on $1^{\text {st }}$ June 2017 that the United States is withdrawing from the Paris Agreement, which was earlier signed under the Obama Administration (The White House Press Release, 2017). This had effectively put the Paris Agreement on hold. Though other major developing countries, such as China and India, have openly declared that they will carry forward their commitments under the Paris Agreement, the future of this Agreement is uncertain as the U.S. is the second-largest emitter of carbon dioxide in the world (Global Carbon Atlas, 2018). The following data summarizes the quantity of $\mathrm{CO}_{2}$ emissions from the first three largest polluters in the world.

Table 1

$\mathrm{CO}_{2}$ Emissions from Countries

\begin{tabular}{llll}
\hline Country & $\begin{array}{l}\text { Share of Cumulative } \mathrm{CO}_{2} \\
\text { emissions (from 1751 to 2017) }\end{array}$ & $\begin{array}{l}\text { Share of Annual } \mathrm{CO}_{2} \\
\text { emissions based on the } \\
\text { year 2017 }\end{array}$ & $\begin{array}{l}\text { Per capita } \mathrm{CO}_{2} \\
\text { emissions based on } \\
\text { the year } 2017\end{array}$ \\
\hline United States & $25 \%$ & $14.58 \%$ & 16.24 tons per capita \\
China & $12.7 \%$ & $27.21 \%$ & 6.98 tons per capita \\
India & $3 \%$ & $6.82 \%$ & 1.84 tons per capita
\end{tabular}

Source: Hannah Ritchie and Max Roser (2020), Published online at ourworlddata.org 
Based on the data in Table 1, from 1751 to 2017, the United States had contributed to 25 percent of cumulative $\mathrm{CO}_{2}$ emissions, while China and India had contributed to 12.7 percent and 3 percent respectively. For the total annual $\mathrm{CO}_{2}$ emissions in the year 2017, the U.S had emitted 14.58 percent, China emitted 27.21 percent and India emitted 6.82 percent. The U.S has the highest cumulative $\mathrm{CO}_{2}$ emissions, compared to both China and India. China was the largest annual $\mathrm{CO}_{2}$ emitter in the world by emitting more than a quarter of the total annual emissions in 2017. However, with regards to the per capita of emissions, the United States has the highest number for $\mathrm{CO}_{2}$ emission at 16.24 tons per capita, while China and India emitted 6.98 tons and 1.84 tons per capita respectively (Hannah Ritchie \& Max Roser; 2020).

The following graph was released by the World Resource Institute that represents the $\mathrm{CO}_{2}$ emissions of countries from 1850 to 2011.

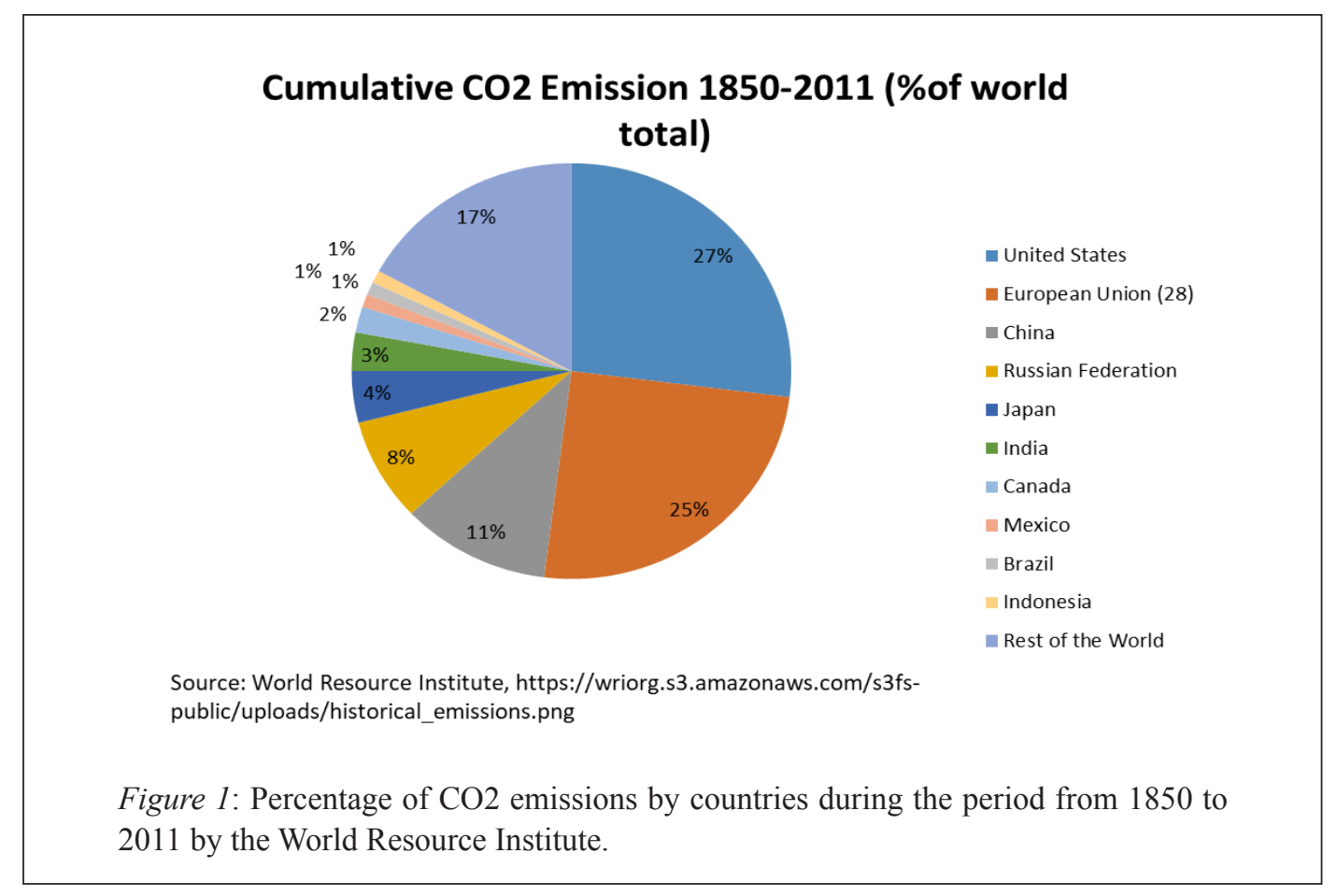

Based the on the data in Figure 1, United States had the highest cumulative $\mathrm{CO}_{2}$ emission than the rest of the world from 1850 to 2011. The chart shows that the United States had emitted 27 percent of the total $\mathrm{CO}_{2}$ emissions, while the European Union and China had emitted a total of 25 percent and 11 percent respectively. The other countries that have contributed to the total $\mathrm{CO}_{2}$ emission from 1850 to 2011 are; Russian Federation (8\%), Japan (4\%), India (3\%), Canada (2\%), Mexico (1\%), Brazil (1\%) and Indonesia (1\%). The majority of countries that are not presented in the chart were grouped together, and have contributed to 17 percent of the total $\mathrm{CO}_{2}$ emissions. 
It is evident from the data presented in Table 1 and Figure 1 that United States has greater responsibility than any other country in the world to help combat climate change. Lieven (2020) has suggested that for the U.S, climate change is a security threat, however, it is perceived from an economic standpoint rather than being viewed as an environmental threat. Military security is an important agenda from the realist paradigm, but so far, it has failed to present valid arguments from a military security standpoint that can tackle climate change effectively (CGSRS, 2015). Habib (2011) asserted that to find the causes of climate change may be beyond the paradigm of realism, and identifying the political aspects that cause climate change falls within the realm of realism. Karlsson and Symons (2014) argued that from the realist perspective, although climate change is a long-term threat to countries, military security is likely to remain the priority for all nation-states. The study further concluded that no country would be willing to surrender their comparative advantage by signing an international climate agreement that would go against their national interests (Karlsson \& Symons, 2014). The United States remain a superpower and a significant player in the international politics of climate change, however, it has not utilized its resources to alter the international structure to favor international cooperation (Sprinz, 1996). U.S. has used defensive and offensive realist arguments to defend its stance on climate change when dealing with major international agreements and policies. Realism as a theory has been successful in explaining the U.S realist position on climate change, however, there is limited literature available that examines the effects of the US decision to address the problem and uphold its international prestige, especially in the wake of Chinese leadership and resolve to combat climate change.

\section{Climate Change and Realism: Theoretical Position}

Theories on international relations, particularly the 'realist theory', has been able to delineate the agendas of different state actors in the global system. Climate change is an issue that has never been regarded by the 'high politics' of realists as they were least interested in addressing the root causes of climate change. Realists consider 'states as the sovereign actors in an international system that are characterized by anarchy' (Waltz, 1979:88). The international system is considered anarchic because there is no overarching authority that regulates the actions and behavior of nation-states (Mearsheimer; 2001:30). Realist theory operates with the basic assumption that all nation-states have their own self-interests in international relations and will always uphold and maintain their self-interest, despite the need to consider the implications of their actions on other states (Morgenthau, 1985; Waltz, 1979). Though realism has different variants such as classical realism, defensive realism and offensive realism, all realists agree that non-state actors could not replace the states at any cost in the international system (Morgenthau, 1985, Waltz, 1979).

With regard to the climate change issue, realists have argued that cooperation is difficult to achieve as the country's interests vary from one another (Grieco, 1990). The realists believe that the international institutions and organizations like the United Nations could not ensure international cooperation on climate change as each country is determined to 
maintain their economic and political advantage. Moreover, the varied interests and mistrust that prevails among the nation-states would make it difficult for cooperation in international climate change forums (Sofer, 2015). For example, the history of UNFCCC negotiations have shown clashes over regulations and provision over the years by many countries. The UNFCCC negotiations were unsuccessful due to the existing differences between countries on equity-related climate change issues. In international relations, countries will act based on cost-benefit analysis (Morgenthau, 1985). O'Riordan and Jordan (1996) concluded that "to understand the ebb and flow of the climate change issue in national and international contexts requires an appreciation of how political power is exercised by different groups in pursuit of their aims and objectives."

For realists, climate change is a political problem rather than a scientific or economic problem (Giddens, 2009). Realists believe that the possibility for consensus-building at the international level is low. They argue that rather than making futile attempts to address this problem at the international level, it is more effective to tackle this issue domestically. Therefore, realists assert that internal and domestic policies are impactful to address the climate change issue, compared to multilateral agreements. Anthony Giddens, in his book 'The Politics of Climate Change' (2009), observed that "in the context of emerging new coalitions like BRIC, competition for natural resources are also becoming more intense, and in one way or the other it is marring the possibilities for international cooperation on the issue." Giddens (2009:227) further claimed that "instead of conducting negotiations involving every single country, countries would be more effective in tackling climate change issue when they work individually, bilaterally or in larger groupings."

In relation to the climate change debate, realists are grouped into two categories; growthfirst realists and sustainable development realists. Generally, growth-first realists argue that climate change debates are posing a threat to the developing countries' interests. Dubash (2012) asserted that "growth first realists view climate change negotiations as a geopolitical stratagem by industrialized countries to contain new and emergent economic powers, particularly China, but also India, Brazil and South Africa." Therefore, growth-first realists place little significance on environmental concerns, however, emphasizes the 'growth' perspective of countries. Growth-first realists suggest that the notion on the foundational demand for equity in climate change burden-sharing is a strategy employed by the developed countries to evade their emission reduction responsibilities and to obstruct the economic growth of developing countries. Furthermore, they argue that the implementation of weak climate change regulations that does not impose strict emission reduction obligations would enable countries, especially developing countries, to grow (2012:202).

On the other hand, sustainable development realists view the impacts of climate change primarily as a security threat, rather than an economic problem (Dubash, 2012). They suggested a shift of the countries' growth first strategy and policies to more environmentally sustainable goals. Sustainable development realists believe that this shift will bring favorable benefits to countries. However, they are skeptical on the outcome of the international climate 
change negotiation processes, under the initiative of the UN, as the developed countries are reluctant to cooperate with developing countries on matters related to climate change (Dubash, 2012). Overall, the realists believe that it is in the hands of the major powers and cooperation between countries that would lead to a solution that could address the issues of climate change. Therefore, there are possibilities that the mechanisms to combat climate change may be shaped in a way that advances the interests of major powers.

\section{Realists on the U.S Withdrawal from the International Climate Agreements}

Porter and Brown (1996) highlighted that "in every global environmental issue, there is one state or a group of states whose cooperation is so essential for the framing of a successful agreement." In the climate change negotiations, the participation of the U.S in the agreement was important in ensuring the success of the UN climate change negotiations due to the country's high emissions and political dominance in the UN. The U.S decision to withdraw from the 1997 Kyoto Protocol was detrimental in the fight to combat the effects of climate change. The future of the Paris Agreement is also undermined after the U.S decision to withdraw from the Agreement that may lead to drastic consequences which could influence the decision of the other states.

The U.S action in the global climate change regime can be better explained with the help of structural realism. While classical realists argue that states are doomed to conflict with the interest of maximizing their power in the international system due to their respective motives, structural realists place lesser importance on human motives. Structural realists argue that states behave in a particular way due to the nature of the international system itself (Waltz, 1979). Structural realists, such as Kenneth Waltz (1979), proclaimed in his book 'Theory of International Politics' that the international system is anarchic, in the absence of an overarching authority that could control the behavior of nation-states. He argued that anarchy and lack of rules have forced the countries to compete or conflict with one another for survival (Waltz, 1979). Structural realism is be divided into two categories; defensive realism and offensive realism. The U.S's response to the global climate change agreements at different periods could be argued with respect to defensive and offensive realism. Hence, it is suggested that the defensive realist argument was predominant in the U.S.'s decision to withdraw from the Kyoto Protocol in 1998, while the offensive realist argument had reflected the U.S.'s decision to withdraw from the Paris Agreement.

\section{U.S and the Kyoto Protocol: Through the Lens of Defensive Realism}

The Kyoto Protocol was the first internationally-binding treaty that contained provisions on fixed targets of emission reduction for developed countries. The Kyoto Protocol met with stiff opposition from the U.S domestic political circles when U.S President Bill Clinton and Vice President Al Gore decided to submit the Protocol for ratification by the U.S Senate in 1997. The U.S Senate passed the Byrd-Hagel resolution (Senate Resolution 98) that dictates that the U.S should not be a signatory to an agreement that exempts key developing countries 
like China and India from the binding emission reduction commitments. There were two main concerns that were highlighted by the Senate's decision. First, the government was concerned that the developing countries, especially China, would have an unfair economic advantage over the U.S as China was exempted from the commitments under the Protocol. Byrd-Hagel Resolution (Senate Resolution 98) was passed by Senate to protect the U.S. manufacturing sector and employment, while the withdrawal from the treaty was to ensure that companies would not move their businesses abroad to take advantage of the relatively limited environmental regulations in the developing countries that would essentially jeopardize the US economy. Second, the Senate concluded that a valid climate treaty requires the participation from developing countries, especially the involvement of China and India, as emissions from these countries have been rapidly growing (Congressional Record 1997 July 25). The ratification of the Byrd Hagel Resolution in July 1997 was a blow to international efforts in addressing climate change, and eventually, the treaty became insignificant.

Defensive realism proposes that the states will not seek to maximize their power in the international system as they are fully aware that any attempt to do so would cause the other states to be insecure, and thereby persuade them to form counter alliances against the rising power (Waltz, 1979). Defensive realists argue that the U.S withdrawal from the Kyoto Protocol and the ratification of the Byrd-Hagel Resolution in the Senate was not for its self-interest to maximize power, but instead, was to maintain its position as the dominant political power within the international system. The U.S was upholding the status quo as the dominant power in the world. For the U.S, by ratifying the Kyoto Protocol, it would lose its position of power in the global system, where it has maintained its influence since after the Cold War. Being the single most significant economic and military power in the world, the U.S did not want to lose out to China, which has hegemonic ambitions and aspirations to challenge the current U.S dominance. The defensive realists further argue that the non-ratification of the Kyoto Protocol was an of self-defense to preserve the sovereignty of the U.S. However, defensive realists are unable to answer the question on whether the U.S would have incorporated the provisions of the Kyoto Protocol into its legislation if India and China were not exempted from the obligations of the treaty.

\section{U.S Withdrawal from the Paris Agreement: An Offensive Realist Approach}

Offensive realism, a different variant of structural realism, proposes that states are aligned towards the enhancement of power, and would maximize their capabilities at the expense of other states (Mearsheimer, 2014). Mearsheimer (2014), an offensive realist, asserts that states are rational actors and that no states can be sure on the actions undertaken by other states. As there are uncertainties regarding the intentions and actions of states, each state would try to maximize its power by enhancing its military and economic capabilities. Mearsheimer (2014) further highlighted that certain states that wish to uphold the status-quo are deemed as 'revisionist powers' if they engage in the efforts to shift the balance of power into their favor. As the international system is characterized by anarchy, states with 
revisionist ambitions may look for opportunities to establish their authority and supremacy at the expense of other states. This would persuade other states to employ offensive realist strategies against the dominant power, resulting in conflict.

The U.S. participation in the Paris Climate Conference in 2015, and the signing of the Paris Agreement under the Obama Administration in April 2016 were considered significant milestones in the history of the UN to combat climate change. However, during the Trump administration, the U.S. withdrew unilaterally from the Paris Agreement on $1^{\text {st }}$ June 2017 (The Whitehouse Press Release, 2017). This was viewed as an offensive move from the U.S administration that had blindsided many developing countries and small island states alike. Although the withdrawal formalities would only be completed in November 2020, the universality of the Paris Agreement has been undermined and stalled a promising global climate change initiative to ensure a better future.

There are many factors that may have influenced President Donald J. Trump's decision to withdraw the U.S. from the Paris Agreement. Dynamics of the U.S domestic politics, U.S. suspicion of the mitigation commitments promised by other countries such as China, and President Trump's personal beliefs were some of the factors that played a role in this decision. Trump believes that the U.S participation in the Paris Agreement would damage US economic prospects and would result to the loss of millions of jobs in the U.S, as the U.S would be forced to comply with the conditions of the Agreement (The White House Press Release, 2017). In 2017, Trump stated that, "the Paris Accord would undermine our economy, hamstring our workers, weaken our sovereignty, impose unacceptable legal risks and put us at a permanent disadvantage to the other countries of the world" (The Whitehouse, 2017).

Furthermore, based on the provisions of the Paris Agreement, the U.S is obliged to contribute to the Green Climate Fund, and thereby finance the developing countries for their climate change mitigation and adaptation efforts (Tabuchi, 16 November 2017). Trump stated that "Green Climate Fund costs the U.S. a vast fortune and U.S has already paid over $\$ 1$ billion" (The Whitehouse, 2017). Other than that, there were reports that indicated the Trump Administration was closely linked with the fossil fuel industry in the U.S (Mayer, 2017). It is widely known that any kind of emission regulation would negatively impact the prospects of the American fossil fuel industry, and therefore, would be detrimental to the Trump Administration's 'America first' policy and U.S economic interests (Cushman \& Hirji; 2016). In addition, President Trump is skeptical about the science of climate change. He has also repeatedly stated that climate change is a 'Chinese hoax' to trick the American people (Dodgson, 2016). His unwillingness to accept the facts of climate change as a real threat to the world had subsequently influenced the U.S. decision to exit the Paris Agreement. While former US President Barack Obama viewed climate change as a real threat, President Trump assumes that climate change is a threat perception projected by China. Hence, Trump believes that by participating in the Agreement, this would be equivalent to surrendering the U.S sovereignty to China. Moreover, the U.S decision to withdraw from the Agreement 
coincides with a trade war that has been ongoing between the U.S and China around the same time. In view of this circumstances, the U.S is skeptical on whether China will remain fully committed to its Paris emission reduction obligations. The U.S. fear of jeopardizing its economy to China resulted in the country's withdrawal from the Agreement.

Defensive realists suggest that the China factor and the fear of economic consequences had influenced the U.S. decision to withdraw from the Paris Agreement. On the other hand, offensive realists suggest that the sole U.S motive to maximize its position of power in the global system had led to its exit. Offensive realists further argue that it is not the US's fear of China's transparency in emission reduction, but the U.S's own ambitions to maximize its international clout that had led to the country's withdrawal. From the offensive realists' point of view, US non-participation in the Paris Agreement would provide freedom without being subjected to any repercussions for its $\mathrm{CO}_{2}$ emission, while China and India (both signatories to the Agreement) will be regulated. Essentially, this would allow the U.S to continue its energy and fossil fuel exploitations, over China and India. The U.S strategy to maximize its power at the cost of other states is a typical offensive realist strategy.

Defensive and offensive realists have agreed that bilateral or multilateral climate cooperation will be difficult to achieve in the current scenario, as states are suspicious of one another's intentions. The withdrawal of U.S from the Agreement will discourage the substantive participation from China and India in the Agreement, even though both countries have openly declared that they will comply with the Agreement (Gowen \& Denyer; 2017). Offensive realists further argued that the U.S abdication of climate responsibility will naturally persuade China and India to not comply with the Paris agreement. However, the exclusion of China and India would clearly result to the early demise of the Paris Agreement. The realist security paradigm is uncertain on whether climate cooperation is possible through the UNFCCC processes. For realists, cooperation is the last resort. They believe that instead of seeking cooperation between states or framing agreements to combat climate change, it is more prudent to develop strategies for domestic implementation to tackle issues of climate change (Grieco, 1988).

\section{Limitations of Realist Position}

One of the main limitations of the realist theory is that it does not offer any solution to address the present climate change problem. Realists are pessimistic on international agreements as they believe that the agreements will fail due to the non-cooperation and mistrust among states. Though realists acknowledge the presence of non-state actors like institutions, business groups and NGO's in the international system, they are considered secondary actors to the states. However, in this globalized world, corporations and NGO's are as important as the states. There are multinational corporations that could drive the country's interest. For example, the Exxon Oil Mobil Cooperation, a company that is based in the U.S, are least interested in emission regulation and continue to be a major player that influences U.S. climate politics. There are reports that point to the decision of former 
U.S President George W. Bush to withdraw from the Kyoto Protocol was due to excessive pressure from this company as this would undermine the company's global dominance through regulated emissions (Revkin, 2005).

Often, the funding of U.S elections and decisions of the ruling government are influenced, and carried out by various corporate groups in the country. The Trump Administration has been subjected to scrutiny from different quarters when it decided to withdraw from the Paris Agreement. There were reports suggesting that President Trump's decision to withdraw from the Paris Agreement was due to the pressure from a petrochemical business group called 'Koch Industries' (Mayer, 2017). Mayer (2017) states that "President Trump may be the face of America's withdrawal from the Paris climate accord, but as deeper reporting is making clear, it is the 'Kochs' and their fellow fossil fuel industry donors who own the policy." If these reports are real, realists have to agree that these non-state actors have played a more significant role than any other countries in the states' policy formulation and decision making. This would disprove the age-old realist contention that the 'institutions and corporations are mere extensions of state power' (Heffron, 2015:14).

\section{Conclusion}

Although the traditional realist paradigm had failed to acknowledge the climate change problem, the dangers that climate change poses for the international community has forced realists to seriously address this issue. However, realists are not concerned on the future of the Paris Agreement, whereby it is the only existing international emission reduction treaty to date. From the realist standpoint, since the U.S interests on climate change was mainly driven by the economic factors and its domestic politics, it is less likely that there would be any changes to the current U.S stance on climate change in the immediate future. However, realists have agreed that the U.S. stance on climate issue has shifted from a defensive realist position that was observed during its withdrawal from Kyoto Protocol, to the offensive realist position when the U.S exited the 2015 Paris Agreement. The U.S. decision to withdraw from the Paris Agreement was a clear indication of the decision to employ an offensive realist strategy in climate politics.

Realists continue to question the implementation of the Paris Agreement in the coming years without the participation of the U.S, which is the second largest $\mathrm{CO}_{2}$ emitter in the world. However, even till today, there are only a few realists who view the climate change issue as a serious threat to the states' existence and survival. Although climate change coalitions and groups have been formed in different parts of the world, realists argue that these alliances would be short-lived as countries are constantly concerned on their absolute gains and losses when deciding to cooperate with other countries. As climate change is a trans-national challenge, the realist's suggestion to resort to domestic policies that addresses the climate change issue would not be sufficient. The multilateral cooperation, particularly between the U.S., China and India, must be preserve to address the climate challenge. The U.S. must take the initiative to come away from its offensive realist climate position. The 
U.S. participation and engagement is prudent for the successful implementation of the Paris Agreement. Climate change is a global challenge that necessitates the substantive participation of all countries. If the issue of climate change is not addressed and a consensus is never reached in the following decades, humanity would be 'the sacing tragedy of commons' (Hardin, 1968).

\section{Acknowledgement}

This research has not received any specific grant from any funding agency.

\section{References}

Centre for Geopolitics and Security in Realism Studies (2015). What do realists think about climate change, CGSRS, Retrieved from http://cgsrs.org/publications/30

Congressional Record (1997, July 25). Expressing sense of senate regarding U.N framework convention on climate change, 143(107), S8113-S8139. Retrieved from http://www. gpo.gov/fdsys/pkg/CREC-1997-07-25/html/CREC-1997-07-25-pt1-PgS8113-6.htm

CRS Report (2015). Greenhouse das pledges by parties to the United Nations framework convention on climate change, Retrieved from Congressional Research Service: https://fas.org/sgp/crs/misc/R44092.pdf

Cushman, J. H., Hirji, Z., Trump: America first on fossil fuels, last on climate change, Inside Climate News (2016 May 27). Retrieved from https://insideclimatenews.org/ news/27052016/donald-trump-republican-party-election-fossil-fuels-coal-oil-gasfracking-climate-change-paris

Dubash, N. K. (2012). Introduction in Dubash N. K. (Ed.), Handbook of climate change and India: Development, politics and governance: New Delhi: Oxford University Press.

Dept. of Climate Change, National Development \& Reform Commission of China (2015, June 30). Enhance actions on climate change: China's intended nationally determined contributions. People's Republic of China.

Dodgson, L., U.S President-elect Donald Trump has publically said he thinks the biggest threat to earth is a Chinese hoax, (2016, November 11). Business Insider. Retrieved from https://www.businessinsider.in/tech/us-president-elect-donald-trump-has-publiclysaid-he-thinks-the-biggest-threat-to-earth-is-a-chinese-hoax/articleshow/55373678. cms.

Giddens, A. (2009). The politics of climate change. Cambridge: Polity Press.

Global Carbon Atlas. Retrieved from http://www.globalcarbonatlas.org/en/CO2-emissions

Government of India (2015). India's intended nationally determined contribution: Working towards climate justice. Ministry of Environment, Forest and Climate Change, 10 December 2016.

Gowen, A., Denyer, S. (2017, June 1). As U.S. backs away from climate pledges, India and China step up, The Washington Post. Retrieved from https://www.washingtonpost. $\mathrm{com} /$ world/asia_pacific/as-us-backs-away-from-climate-pledges-india-and-chinastep-up/2017/06/01/59ccb494-16e4-4d47-a881-c5bd0922c3db_story.html 
Grieco, J. M. (1988). Anarchy and the limits of cooperation: A realist critique of the newest liberal institutionalism, International Organization, 42(3), 485-507.

Grieco, J. M. (1990). Cooperation among nations: Europe, America and non-tariff barriers to trade. Ithaca. New York: Cornell University Press.

Habib, B., (2011). Climate Change and international relations theory: North East Asia as a Case Study. Third Global International Studies Conference, Portugal. Retrieved from https://drbenjaminhabib.files.wordpress.com/2011/09/habib-b_wisc2011_climatechange-ir-theory-northeast-asia-case-study.pdf

Hannah R., Max R. (2020). $\mathrm{CO}_{2}$ and greenhouse gas emissions; Published online at ourworlddata.org; Retrieved from https://ourworldindata.org/co2-and-othergreenhouse-gas-emissions.

Hardin, G. (1968). The tragedy of commons. In Art, R. and Jervis, R (2015). International Politics: Enduring Concepts and Contemporary Issues. Harrow: Pearson.

Heffron, D. (2015). What do realists think about climate politics? London: UK; Centre for Geopolitics and Security in Realism Studies.

IPCC (2007). Climate change 2007: Synthesis Report. Geneva: IPCC, Retrieved from http:// www.ipcc.ch/publications_and_data/ar4/syr/e...

IPCC (2014). Contribution of working groups I, II and III to the fifth assessment report of the Intergovernmental Panel on Climate Change. Core Writing Team, R.K Pachauri and L.A. Meyer (Eds.). In Climate Change 2014; Synthesis Report. Geneva, Switzerland: IPCC.

Karlsson, R., Symons J. C (2014). Scalability and realist climate insights. Weather, climate and society. 6(3): 289-292. Retrieved from https://journals.ametsoc.org/wcas/ article/6/3/289/969/Scalability-and-Realist-Climate-Insights

Kyoto Protocol to the United Nations Framework Convention on Climate Change (1997, December 10). UN Doc.FFCC/CP/1997/L.7/Add.1, Annex B. Retrieved from http:// unfccc.int/resource/docs/convkp/kpeng.pdf

Lieven, A., (2000). Climate change and the state: A case for environmental realism. Survival, $62(2), 7-26$.

Masum, A. (2013). The right to development and its corresponding obligation on developing countries. Journal of International Studies (JIS), 9. Retrieved from http://jis.uum. edu.my/images/pdf/9jis/jis92.pdf

Mayer, J. (2017, June 5). In the withdrawal from the Paris climate agreement, The Koch Brothers' Campaign Becomes Overt, The New Yorker, New York. Retrieved https:// www.newyorker.com/news/news-desk/in-the-withdrawal-from-the-paris-climateagreement-the-koch-brothers-campaign-becomes-overt

Meadowcroft, J. (2010). Climate change governance. Policy Research Working Paper to the 2010 World Development Report. Retrieved from http://documents.worldbank.org/ curated/en/210731468332049368/pdf/WPS4941.pdf

Mearsheimer, J. J. (2014). Can China rise peacefully? National Interest. Retrieved from https://nationalinterest.org/commentary/can-china-rise-peacefully-10204

Mearsheimer, J. (2001). The tragedy of great power politics. New York: Horton.

Morgenthau, H. (1985). Politics among nations: The pursuit of power and peace. Chicago, Chicago University Press. 
O' Riordan, T., \& Jordan, A. (1996). Social institutions and climate change, in T. O' Riordan and J. Jaeger (Ed.), The Politics of climate change: A European perspective. London and New York: Routledge.

Porter, G., \& Brown, J. (1996). Global environmental politics. Boulder: Westview Press.

Revkin, A. (2005). Ex-Bush aide who edited climate reports to join ExxonMobil. The New York Times, 10(3), 12-17.

Senate Resolution 98, (1997, July 25). The transcript of the Senator floor debate and the Byrd-Hagel Resolution is found in "Expressing the sense of Senate regarding U.N Framework Convention on Climate Change," Congressional Record: S8 113-S8139. Retrieved from http://www.nationalcenter.org/KyotoSenate.html

Sofer, K. (2015). The Realist case for climate change cooperation. Centre for American Progress, 30 November 2015. Retrieved from https://www.americanprogress. org/issues/security/news/2015/11/30/126356/the-realist-case-for-climate-changecooperation/

Sprinz, D., Lutebacher, U. (1996). International relations and global climate change. Postdam Institute for Climate Impact Research (PIK). Retrieved from https://www. pik-potsdam.de/research/publications/pikreports/.files/pr21.pdf

Tabuchi, H. (2017, November 16). UN climate projects aimed at the poorest, raise red flags. The New York Times. New York.

The Whitehouse (2017, June 1). Statement by President Trump on the Paris climate accord. Retrieved from https://www.whitehouse.gov/the-press-office/2017/06/01/statementpresident-trump-paris-climate-accord

UNFCCC (1992). United Nations framework convention on climate change. New York: UN. Retrieved from https://unfccc.int/resource/docs/convkp/conveng.pdf

UNFCCC (2015, December 12). Adoption of the Paris agreement. FCCC/CP/2005L.9/ Rev.1. Retrieved from https://unfccc.int/resource/docs/2015/cop21/eng/109r01.pdf

Vinodan, C., \& Kurian, A. L. (2015). Energy security and climate change: India's responses to the challenges'. Journal of International Studies, 11, 29-47. Retrieved from http:// jis.uum.edu.my/images/pdf/11jis/3vol112015.pdf

Waltz, K. (1979). Theory of international politics. Boston, MA: Mc Graw-Hill 